\title{
Impact of Admission Month on Outcomes in Spontaneous Subarachnoid Hemorrhage: Evidence Against the March Effect
}

\author{
Hyun Su Kim, Cheol Wan Park, Chan Jong Yoo, Eun Young Kim, Young Bo Kim, Woo Kyung Kim \\ Department of Neurosurgery, Gil Medical Center, Incheon, Gachon University, Republic of Korea
}

Objective : We attempted to identify the presence of a so called 'March effect (or phenomenon)' (which had long been known as a 'July effect' in western countries), a transient increase in adverse outcomes during an unskilled period for new interns and residents in a teaching hospital, among a cohort of patients with spontaneous subarachnoid hemorrhage (sSAH).

Methods : A total of 455 consecutive patients with sSAH from our department database from 2008 to 2010 were enrolled retrospectively and the admission month, patient demographics and clinical characteristics, treatment modalities and discharge outcomes were analyzed. Multivariate regression analysis was used to determine whether unfavorable discharge and in-hospital mortality showed a significant increase during the unskilled months for new interns and residents (from March to May) in a pattern suggestive of a "March effect".

Results: Among 455 patients with SSAH, 113 patients were treated during the unskilled period (from March to May) and the remaining 342 patients were treated during the skilled period (from June until February of the next year). No statistically significant difference in demographics and clinical characteristics was observed between patients treated during these periods. In addition, the mortality and unfavorable discharge rates of the un-skilled period were $16.8 \%$ and $29.7 \%$ and those of the skilled period were $15.5 \%$ and $27.2 \%$, respectively. However, no statistically significant difference was observed between them.

Conclusions : Findings of our study suggest that there was no 'March effect' on the mortality rate and unfavorable discharge rate among patients with SSAH in our hospital during the study period.

Keywords Spontaneous subarachnoid hemorrhage, March effect, Mortality rate, July effect, Teaching hospital

\author{
J Cerebrovasc Endovasc Neurosurg. \\ 2013 June; 15(2):67 75 \\ Received : 18 March 2013 \\ Revised : 7 May 2013 \\ Accepted : 27 May 2013 \\ Correspondence to Cheol Wan Park \\ Department of Neurosurgery \\ Gil Medical Center, Gachon University \\ 1198 block, Guweol-Dong, Namdong-Gu \\ Incheon, 405-220 Republic of Korea \\ Tel : 82-32-460-3304 \\ Fax : 82-32-460-3899 \\ E-mail : cwpark@gilhospital.com
}

This is an Open Access article distributed under the terms of the Creative Commons Attribution NonCommercial License /http://creativecommons.org/licenses/by-nc/3.0) which permits unrestricted noncenses/by-nc/3.0) which permits unrestricted nonmedium, provided the original work is properly cited.

\section{INTRODUCTION}

Spontaneous subarachnoid hemorrhage (sSAH) is still a challenging neurosurgical disease entity. Emergency and elective care of SSAH is critical given that cerebral vasospasm, rebleeding, increased intracranial pressure due to acute brain swelling, related intra-parenchymal hemor- rhage, or acute hydrocephalus, hemodynamic instability, cerebral infarction, seizure, electrolytes imbalances and cardiac rhythm abnormalities due to myocardial injury are all possible life-threatening complications. ${ }^{51017)}$

Surprisingly, the unnoticed SSAH remains as high as $12 \%$, resulting in four-fold higher rates of morbidity and mortality. ${ }^{16)}$ A common comment from a variety 
of studies suggests that early identification and treatment of sSAH and related complications are critical components to achievement of desirable outcomes.)

Meanwhile, thorough reappraisal of educational programs for training of interns and residents in western countries has increased due to results suggesting an increment in unacceptable outcomes in the late summer (that falls during the spring in Korea), which is the unskilled season for beginner interns and residents. ${ }^{23)}$ This tendency, termed a "July effect" in western countries has come from the July inrush of inexperienced interns and residents of the first year. Because the training hospital workforce is highly dependent on intern and resident doctors for duty, especially for night time and emergency room, they stand for the first line of care at these hospitals and may frequently be urged to make acute management decisions and provide care with limited guidance. Because reliable clinical evidence indicates that favorable outcomes in SSAH may be associated with early identification of the disease, rigid compliance to clinical management guidelines and experience and knowledge of corresponding physicians could play a considerable role in such outcomes. ${ }^{5)}$ In Korea, a similar phenomenon might have occurred in March because of the difference in the period of educational systems between western countries and Korea. Some clinical studies on the "July effect" have been reported; on the contrary, no available study on the 'March effect' has been conducted in Korea, especially in the neurosurgical field. The authors attempted to identify a 'March effect', defined as a temporary increase in the frequency of adverse outcomes (mortality rate and unfavorable discharge rate), among a cohort of patients admitted to our hospital under the diagnosis of sSAH.

\section{METHODS}

\section{Study setting and Patient enrollment}

From January 2008 to December 2010, 455 consecutive patients with an acute form of spontaneous sub- arachnoid hemorrhage were admitted to the author's hospital. Traumatic SAH was excluded. All patients underwent routine clinical and radiographic evaluations and the authors made decisions on how to treat the patients according to their clinical and radiological information and neurological status and then obtained informed consent from the patient's family; surgical clipping, endovascular coiling and conservative therapy (including external ventricular drainage and medical treatment). The authors prefer early surgical clipping or early endovascular intervention to delayed ones. The enrolled patients were divided into four groups according to their admission month; Quarter 1 (March -May), Quarter 2 (June -August), Quarter 3 (September -November) and Quarter 4 (December - next year February). We hypothesized that new interns and new first year residents became more experienced and more skilled with passage of time. Therefore, Quarter 1 was the most unskilled period, whereas Quarter 4 was the most skilled period.

Admission month, demographic and clinical characteristics (age, sex and number of chronic conditions, such as diabetes, hypertension and chronic obstructive lung disease), treatment (length of stay, type of procedures performed) and outcome (in-hospital mortality and unfavorable discharge rates; which means worse discharge Glasgow coma scale (GCS) score than first admission GCS score) variables were obtained from the clinical records and radiographic studies of involved patients.

\section{Statistical analysis}

All retrieved data were converted into categorical or binominal variables. The statistical relationships were assessed using one-way analysis of variance (ANOVA), logistic regression analysis, multiple regression analysis and Cox regression analysis; and additional survival analysis was performed in order to examine the effect of admission quarter on unfavorable discharge and mortality rate of sSAH patients. Statistical significance was accepted for a $p$ value of $<0.05$. 
Table 1. General clinical variables of involved patients

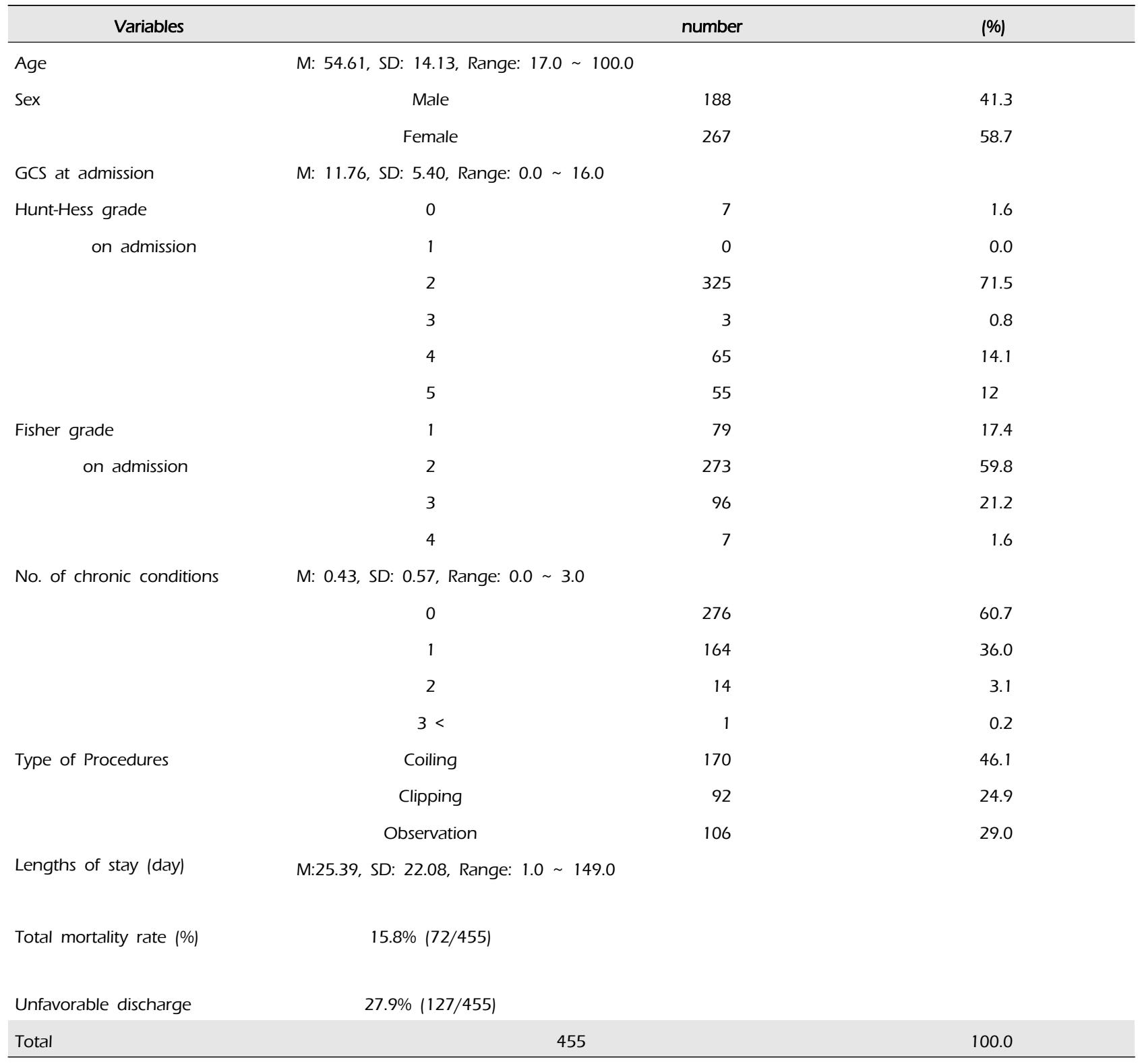

GCS= Glasgow coma scale; $M=$ mean; $S D=$ standard deviation

\section{RESULTS}

A total of 455 consecutive patients with sSAH between January 2008 and December 2010 were retrospectively enrolled in the present study. Their mean age was approximately 54 years (54.61) and sex ratio was approximately 4:6 (Male: Female $=41.3 \%$ : 58.7\%). A summary of patients' clinical information is shown in Table 1 and more detailed information according to the admission month is shown in Table 2.

Four groups (quarter 1 to 4 ), divided according to their admission month, did not show statistically significant difference in their clinical characteristics, including age, Hunt-Hess and Fisher grades at admission and type of treatment procedures (Table 3).

\section{Mortality rate}

Mortality rates of each quarter were $16.8 \%$ in quar- 
MARCH EFFECT IN SPONTANEOUS SAH

Table 2. Characteristics of involved patients by admission month

\begin{tabular}{|c|c|c|c|c|c|c|c|c|c|c|c|c|}
\hline & Jan & Feb & Mar & Apr & May & Jun & Jul & Aug & Sep & Oct & Nov & Dec \\
\hline $\begin{array}{l}\text { No. of } \\
\text { admission } \\
\text { patients }\end{array}$ & 51 & 33 & 32 & 34 & 47 & 40 & 36 & 38 & 35 & 34 & 42 & 33 \\
\hline Age & $\begin{array}{l}55.59 \pm \\
16.68\end{array}$ & $\begin{array}{l}56.00 \pm \\
13.40\end{array}$ & $\begin{array}{l}55.41 \pm \\
15.69\end{array}$ & $\begin{array}{l}55.5 \pm \\
13.80\end{array}$ & $\begin{array}{l}52.34 \pm \\
12.34\end{array}$ & $\begin{array}{l}53.47 \pm \\
12.72\end{array}$ & $\begin{array}{l}53.81 \pm \\
13.90\end{array}$ & $\begin{array}{l}52.26 \pm \\
16.49\end{array}$ & $\begin{array}{l}55.26 \pm \\
12.70\end{array}$ & $\begin{array}{l}55.12 \pm \\
13.68\end{array}$ & $\begin{array}{l}55.17 \pm \\
14.58\end{array}$ & $\begin{array}{l}56.30 \pm \\
13.43\end{array}$ \\
\hline $\begin{array}{l}\text { GCS score on } \\
\text { admission }\end{array}$ & $\begin{array}{c}11.34 \pm \\
5.85\end{array}$ & $\begin{array}{l}12.57 \pm \\
4.58\end{array}$ & $\begin{array}{l}9.56 \pm \\
6.00\end{array}$ & $\begin{array}{l}10.47 \pm \\
6.15\end{array}$ & $\begin{array}{c}12.60 \pm \\
5.07\end{array}$ & $\begin{array}{l}12.13 \pm \\
4.78\end{array}$ & $\begin{array}{l}12.44 \pm \\
4.86\end{array}$ & $\begin{array}{l}11.47 \pm \\
5.85\end{array}$ & $\begin{array}{l}11.83 \pm \\
5.52\end{array}$ & $\begin{array}{l}11.97 \pm \\
5.46\end{array}$ & $\begin{array}{l}10.84 \pm \\
6.22\end{array}$ & $\begin{array}{l}13.77 \pm \\
3.29\end{array}$ \\
\hline $\begin{array}{l}\text { Hunt-Hess } \\
\text { grade on } \\
\text { admission }\end{array}$ & $\begin{array}{l}2.97 \pm \\
1.21\end{array}$ & $\begin{array}{l}2.64 \pm \\
1.16\end{array}$ & $\begin{array}{l}2.64 \pm \\
1.32\end{array}$ & $\begin{array}{l}2.73 \pm \\
1.17\end{array}$ & $\begin{array}{l}2.71 \pm \\
1.20\end{array}$ & $\begin{array}{l}2.50 \pm \\
1.08\end{array}$ & $\begin{array}{l}2.56 \pm \\
1.16\end{array}$ & $\begin{array}{l}2.65 \pm \\
1.48\end{array}$ & $\begin{array}{l}2.45 \pm \\
1.15\end{array}$ & $\begin{array}{l}2.61 \pm \\
1.03\end{array}$ & $\begin{array}{l}2.73 \pm \\
1.17\end{array}$ & $\begin{array}{l}2.19 \pm \\
0.60\end{array}$ \\
\hline $\begin{array}{l}\text { Fisher grade } \\
\text { on admission }\end{array}$ & $\begin{array}{l}3.28 \pm \\
0.53\end{array}$ & $\begin{array}{l}3.18 \pm \\
0.55\end{array}$ & $\begin{array}{l}3.16 \pm \\
0.69\end{array}$ & $\begin{array}{l}2.97 \pm \\
0.72\end{array}$ & $\begin{array}{l}2.97 \pm \\
0.75\end{array}$ & $\begin{array}{l}2.91 \pm \\
0.64\end{array}$ & $\begin{array}{l}2.88 \pm \\
0.78\end{array}$ & $\begin{array}{l}2.71 \pm \\
0.94\end{array}$ & $\begin{array}{l}2.79 \pm \\
0.73\end{array}$ & $\begin{array}{l}3.06 \pm \\
0.50\end{array}$ & $\begin{array}{l}3.22 \pm \\
0.53\end{array}$ & $\begin{array}{l}2.97 \pm \\
0.41\end{array}$ \\
\hline $\begin{array}{l}\text { No. of chronic } \\
\text { disease (mean) }\end{array}$ & $\begin{array}{l}0.41 \pm \\
0.54\end{array}$ & $\begin{array}{l}0.42 \pm \\
0.56\end{array}$ & $\begin{array}{l}0.56 \pm \\
0.62\end{array}$ & $\begin{array}{l}0.47 \pm \\
0.51\end{array}$ & $\begin{array}{l}0.43 \pm \\
0.62\end{array}$ & $\begin{array}{l}0.40 \pm \\
0.59\end{array}$ & $\begin{array}{l}0.42 \pm \\
0.50\end{array}$ & $\begin{array}{l}0.53 \pm \\
0.56\end{array}$ & $\begin{array}{l}0.51 \pm \\
0.66\end{array}$ & $\begin{array}{l}0.35 \pm \\
0.54\end{array}$ & $\begin{array}{l}0.31 \pm \\
0.47\end{array}$ & $\begin{array}{l}0.36 \pm \\
0.65\end{array}$ \\
\hline \multicolumn{13}{|l|}{ Procedure type } \\
\hline coil & $8(25.8)$ & $17(60.7)$ & $12(48.0)$ & $12(40.0)$ & $16(45.7)$ & $14(45.2)$ & $14(56.0)$ & $15(44.1)$ & $15(51.7)$ & $12(36.4)$ & $16(43.2)$ & $19(61.3)$ \\
\hline clipping & 13(41.9) & $8(28.6)$ & $6(24.0)$ & $6(20.0)$ & $7(20.0)$ & $10(32.3)$ & $5(20.0)$ & $8(23.5)$ & $3(10.3)$ & $13(39.4)$ & $8(21.6)$ & $5(16.1)$ \\
\hline observation & $10(32.3)$ & $3(10.7)$ & $7(28.0)$ & 12(40.0) & $12(34.3)$ & $7(22.6)$ & $6(24.0)$ & $11(32.4)$ & $11(37.9)$ & $8(24.2)$ & $13(35.1)$ & $7(22.6)$ \\
\hline $\begin{array}{l}\text { Length of } \\
\text { hospital (day) }\end{array}$ & $\begin{array}{l}26.14 \pm \\
25.92\end{array}$ & $\begin{array}{l}28.25 \pm \\
23.71\end{array}$ & $\begin{array}{l}22.36 \pm \\
15.78\end{array}$ & $\begin{array}{l}21.87 \pm \\
17.38\end{array}$ & $\begin{array}{l}28.60 \pm \\
27.03\end{array}$ & $\begin{array}{l}19.06 \pm \\
13.6\end{array}$ & $\begin{array}{l}34.16 \pm \\
26.87\end{array}$ & $\begin{array}{l}26.03 \pm \\
22.19\end{array}$ & $\begin{array}{l}23.14 \pm \\
26.53\end{array}$ & $\begin{array}{l}28.39 \pm \\
25.43\end{array}$ & $\begin{array}{l}22.76 \pm \\
18.42\end{array}$ & $\begin{array}{l}25.13 \pm \\
16.55\end{array}$ \\
\hline Mortality rate (\%) & $29.4 \%$ & $13.8 \%$ & $23.1 \%$ & $23.1 \%$ & $9.3 \%$ & $5.6 \%$ & $9.7 \%$ & $21.4 \%$ & $16.0 \%$ & $13.3 \%$ & $26.7 \%$ & $3.3 \%$ \\
\hline $\begin{array}{l}\text { Unfavorable } \\
\text { discharge (\%) }\end{array}$ & $33.3 \%$ & $21.9 \%$ & $38.5 \%$ & $36.7 \%$ & $17.1 \%$ & $31.3 \%$ & $25.0 \%$ & $23.5 \%$ & $34.5 \%$ & $27.3 \%$ & $27.0 \%$ & $20.0 \%$ \\
\hline
\end{tabular}

no= number

Table 3. Characteristics of patients by admission quarter

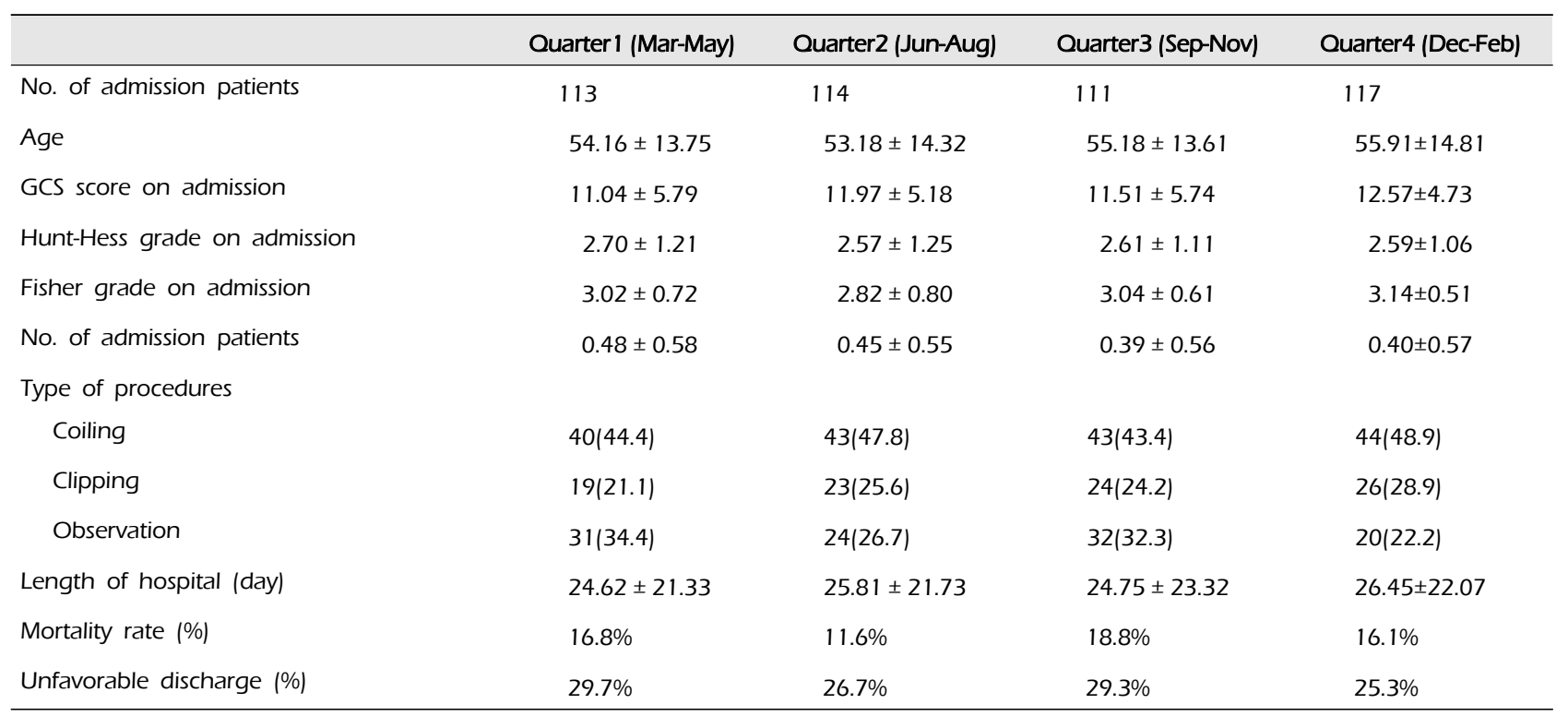

Period setting: quarterly phage 


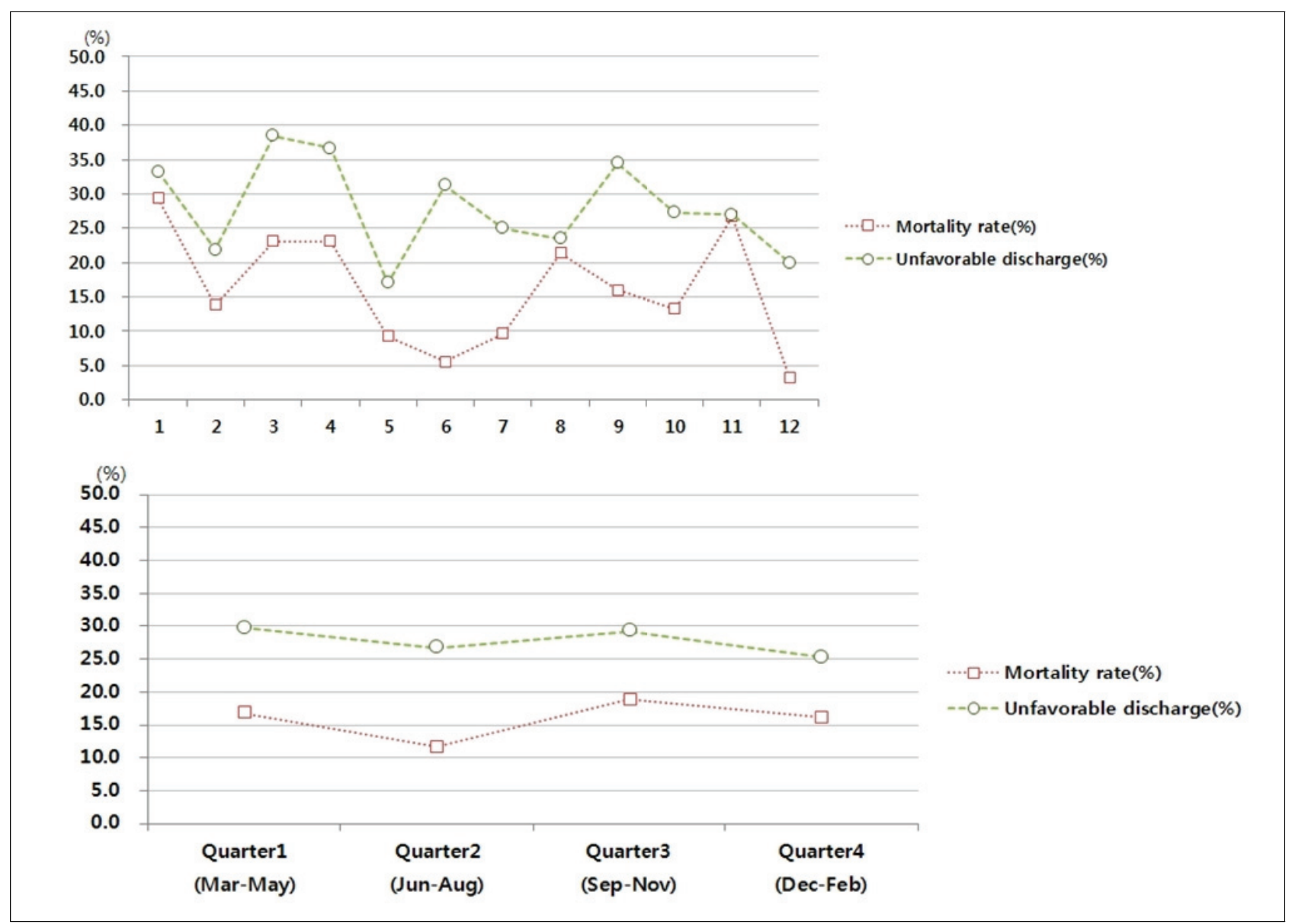

Fig. 1. Mortality rate and unfavorable discharge

ter $1,11.6 \%$ in quarter $2,18.8 \%$ in quarter 3 and $16.1 \%$ in quarter 4 (Table 3, Fig. 1).

Through logistic regression analysis for identification of factors having an influence on patients' mortality rate, conservative therapy (Hazard Ratio $[\mathrm{HR}]=2.3, p=0.035)$ was the only statistically significant factor associated with mortality rate regardless of admission quarter. All other investigated clinical variables, including age $(\mathrm{HR}=1.0, p=0.707)$, admission GCS score $(\mathrm{HR}=0.1, p=0.477)$, Hunt-Hess grade at admission $(\mathrm{HR}=1.1, p=0.546)$, Fisher grade at admission $(\mathrm{HR}=0.5, p=0.107)$, mean number of chronic diseases $(\mathrm{HR}=1.1, p=0.726)$ and coiling procedure $(\mathrm{HR}=1.0, p=0.090)$ / surgical clipping $(\mathrm{HR}=1.2$, $p=0.768)$ did not show a statistically significantly association with mortality rate of the patients (Table 4).
In additional log-rank analysis, no statistically significant difference in mortality rate was observed with respect to the admission quarter (Chi square = 2.408, degree of freedom $[\mathrm{Df}]=3, p=0.492$ ) (Fig. 2).

\section{Unfavorable discharge rate}

With the logistic regression analysis, admission GCS score $(\mathrm{HR}=2.0, p=0.000)$ and Hunt-Hess grade at admission $(\mathrm{HR}=2.6, p=0.035)$ showed a statistically significantly association with unfavorable discharge of patients (Table 5). In additional log-rank analysis, no statistically significant difference in the unfavorable discharge rate was observed with respect to the admission quarter (Chi square $=2.205, \mathrm{Df}=3, p=0.531$ ) (Fig. 3). 
Table 4. Comparative analysis of factors that influence mortality rate

\begin{tabular}{|c|c|c|c|}
\hline & $\mathrm{HR}$ & $95 \% \mathrm{Cl}$ & $P$ value \\
\hline Age & 1.0 & $0.976-1.017$ & 0.707 \\
\hline GCS score on admission & 0.1 & $0.000-65.471$ & 0.477 \\
\hline \multicolumn{4}{|l|}{ on admission } \\
\hline Fisher grade on admission & 0.5 & $0.260-1.141$ & 0.107 \\
\hline No. of admission patients & 1.1 & $0.593-2.119$ & 0.726 \\
\hline \multicolumn{4}{|l|}{ Type of procedures } \\
\hline Coiling & 1.0 & Referent & 0.090 \\
\hline Clipping & 1.2 & $0.353-4.094$ & 0.768 \\
\hline Observation & 2.3 & $1.060-4.793$ & 0.035 \\
\hline
\end{tabular}

$\mathrm{HR}=$ hazard ratio; $\mathrm{Cl}=$ confidence interval

\section{DISCUSSION}

The 'July phenomenon or effect' in western countries (called a 'March effect' in our study) has been studied across different medical specialties, including general surgery, obstetrics and gynecology and internal medicine. 24)5)8)10)14)18(20)21)27) Evidence of or against the presence of a 'July effect' has been inconsistent. The principal causes for discordance among published studies are likely a function of several phenomena. First, many of these studies derived their data from single-center populations and thus may more accurately reflect the clinical and educational practice patterns of a particular hospital. Second, smaller studies may have failed to normalize data on changes in seasonal practice patterns, which may falsely manifest as relative changes in outcomes. Third, as in our study, complete information regarding long-term outcomes and prognosis were not available in the database and thus could not be used as outcome metrics. Fourth, differing end points and adverse outcome metrics were used among the different studies, including ours, making inter-study comparisons difficult.

The majority of studies on the 'July effect' have found no meaningful difference in patient outcomes in July compared to other months. Buchwald et al.,') who evaluated neck and back problems, found no in- crease in the length of hospital stay for July admissions, compared with May. Banco et al., ${ }^{2)}$ who focused on the incidence of perioperative spinal infection rates at different times during the academic year. They found no association between infection rates in the month of July or other times of the year when residents or fellows were new on the service.

On the other hand, some studies have demonstrated a 'July effect'. In a recent study, after examining all available US death certificates from 1979 to 2006, Phillips and Barker ${ }^{23)}$ reported a $10 \%$ increase in fatal

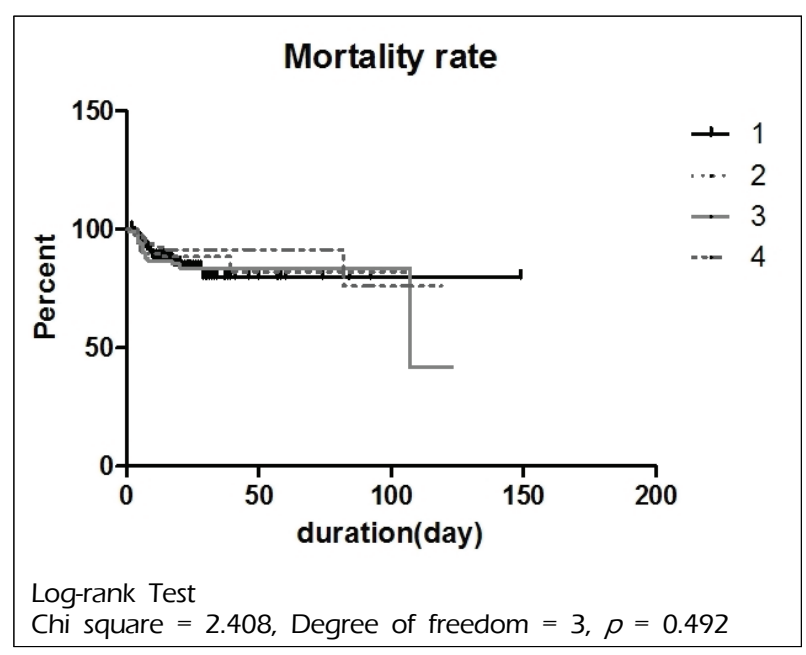

Fig. 2. Statistical analysis of mortality rate according to admission quarter 
Table 5. Comparative analysis of factors that influence unfavorable discharge

\begin{tabular}{|c|c|c|c|}
\hline & OR & $95 \% \mathrm{Cl}$ & $P$ value \\
\hline Age & 1.0 & $0.942-1.012$ & 0.193 \\
\hline GCS score on admission & 2.0 & $1.648-2.462$ & 0.000 \\
\hline $\begin{array}{l}\text { Hunt-Hess grade } \\
\text { on admission }\end{array}$ & 2.6 & $1.070-6.110$ & 0.035 \\
\hline Fisher grade on admission & 1.1 & $0.423-3.030$ & 0.806 \\
\hline $\begin{array}{l}\text { No. of admission patients } \\
\text { procedure type }\end{array}$ & 0.8 & $0.364-1.765$ & 0.583 \\
\hline Coil & 0.7 & $0.240-2.080$ & 0.529 \\
\hline Clipping & 2.6 & $0.594-11.306$ & 0.205 \\
\hline Observation & 1.0 & Referent & \\
\hline
\end{tabular}

$\mathrm{OR}=$ odds ratio

medical errors in the inpatient, outpatient and emergency room setting. Englesbe et al. ${ }^{11)}$ reported an increase in postoperative mortality of $41 \%$ among patients treated by interns within the American College of Surgeons National Surgical Quality Improvement Program. One study reported a slight increase in overall surgical mortality during the years 1991 to 1997 at teaching hospitals. ${ }^{4)}$ Walling and Veremakis ${ }^{28)}$ reported that first-year residents made more prescribing errors during early months of their training compared with later in the year. In addition, Inaba et al. ${ }^{14)}$ demonstrated an increased risk of errors resulting in preventable or potentially preventable complications at the beginning of the academic year (July and August) compared with the end of the academic year (May and June) at an academic trauma center.

To the best of the author's knowledge, no neurosurgical studies on the 'July effect (March effect)' have been conducted in Korea. In this retrospective, cohort study of 455 consecutive sSAH admissions, we found no statistically significant increase in the mortality or unfavorable discharge rate for the month of March in our hospital compared with all other months.

In the present study, there are several limitations. First, this study is a retrospective study, which has the potential for analytic limitations in some clinical variables and situations, such as medical errors and adverse events. Second, possible limitation is the risks inherent to emergency cases. Given the circumstances of the tertiary emergency room, there are a few potentials for misdiagnosis at admission, which may result in inaccurate mortality and/or unfavorable discharge rates. Third, there is another limitation of the retrospective study. We were not able to analyze the rates of complications and near misses that were not associated with mortality or unfavorable discharges, committed by neurosurgery interns and residents, especially during management in the intensive care unit, which may be a more sensitive tool for evalua-

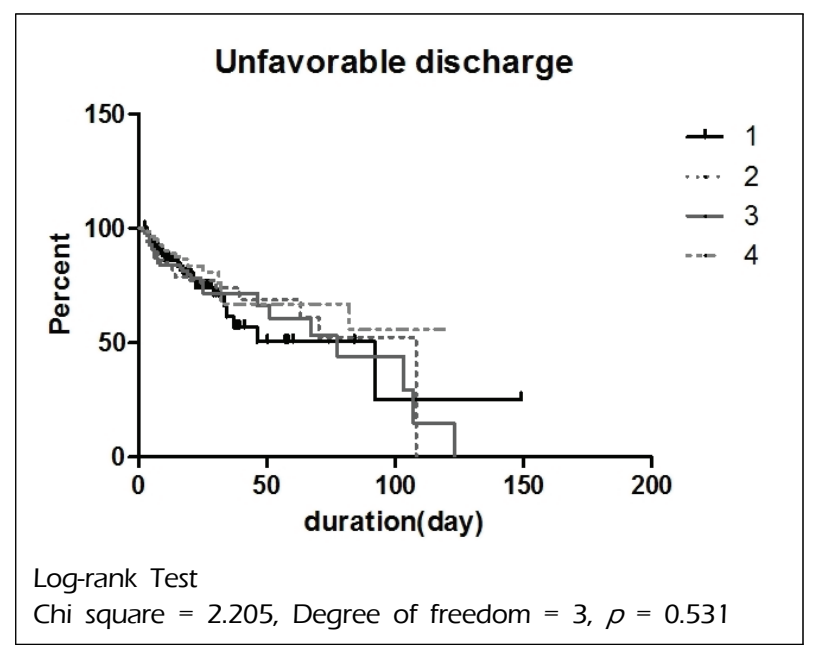

Fig. 3. Statistical analysis of unfavorable discharge according to admission quarter 
tion of a 'March effect'. Fourth, one of the limitations to this study is that our data are limited to in-hospital observations. Therefore, mortality occurring after discharge would not be assessed. However, because complications and medical errors, which resulted in death of the patients, committed by neurosurgery interns and residents are most likely going to be in-hospital and not after discharge, we believe that this should not have a significant effect on the result of our study. Fifth, the temporal resolution is limited to monthly intervals and fluctuations in adverse outcomes over time periods shorter than one month would not be detected in the current study, especially if the rotation schedules of interns are shorter than one month. And, finally, we did not consider the clinical experience of the surgeons performing surgical clipping and/or endovascular interventions in our hospital, which might be the most important factor influencing the patients' outcome. However, cases of each surgeon were evenly allocated over one year, which might not have an effect on the monthly variation of patients' outcome.

Generally speaking, it is reasonable to assume that at the start of an academic year, a number of errors made by interns and residents would be higher compared with later months. Alternatively, the absence of a "March effect (July effect)" may be attributable to the increased supervision by more senior residents and faculties during the start of the academic year.

\section{CONCLUSION}

Findings of our study suggest that the 'March effect' was not found for neurosurgical mortality or unfavorable discharge rates in patients with $\mathrm{SSAH}$ in the author's hospital. Even with some limitations, our study adds to the limited knowledge on the 'March effect' in the field of neurosurgery. In order to establish a 'March effect' in the neurosurgical field, including sSAH, a meta-analysis from multi-institutional prospective study is anticipated.

\section{REFERENCES}

1. Aylin P, Majeed FA. The killing season-fact or fiction. BMJ. 1994 Dec;309(6970):1690.

2. Banco SP, Vaccaro AR, Blam O, Eck JC, Cotler JM, Hilibrand AS, et al. Spine infections: variations in incidence during the academic year. Spine (Phila Pa 1976). 2002 May;27(9):962-5.

3. Barger LK, Cade BE, Ayas NT, Cronin JW, Rosner B, Speizer FE, et al. Extended work shifts and the risk of motor vehicle crashes among interns. $N$ Engl J Med. 2005 Jan;352(2):125-34

4. Barry WA, Rosenthal GE. Is there a July phenomenon? The effect of July admissions on intensive care morality and length of stay in teaching hospitals. J Gen Intern Med. 2003 Aug;18(8):639-45.

5. Bederson JB, Connolly ES Jr, Batjer HH, Dacey RG, Dion JE, Diringer MN, et al. Guidelines for the management of aneurysmal subarachnoid hemorrhage: a statement for healthcare professionals from a special writing group of the Stroke Council, American Heart Association. Stroke. 2009 Mar;40(3):994-1025.

6. Blumberg MS. Measuring surgical quality in Maryland: a model. Health Aff (Millwood). 1988 Feb;7(1):62-78.

7. Buchwald D, Komaroff AL, Cook EF, Epstein AM. Indirect costs for medical education. Is there a July phenomenon? Arch Intern Med. 1989 Apr;149(4):765-8.

8. Claridge JA, Schulman AM, Sawyer RG, Ghezel-Ayagh A, Young JS. The 'July phenomenon' and the care of the severely injured patient: fact or fiction? Surgery. 2001 Aug;130(2):346-53.

9. Davydov L, Caliendo G, Mehl B, Smith LG. Investigation of correlation between house-staff work hours and prescribing errors. Am J Health Syst Pharm. 2004 Jun;61(11):1130-4.

10. Diringer MN. Management of aneurysmal subarachnoid hemorrhage. Crit Care Med. 2009 Feb;37(2):432-40.

11. Englesbe MJ, Pelletier SJ, Magee JC, Gauger P, Schifftner $\mathrm{T}$, Henderson WG, et al. Seasonal variation in surgical outcomes as measured by the American College of Surgeons-National Surgical Quality Improvement Program (ACS-NSQIP). Ann Surg. 2007 Sep;246(3):456-62; discussion 463-5.

12. Finkielman JD, Moreles J, Peters SG, Keegan MT, Ensminger SA, Lymp JF, et al. Mortality rate and length of stay of patients admitted to the intensive care unit in July. Crit Care Med. 2004 May;32(5):1161-5.

13. Friedman WA. Resident duty hours in American neurosurgery. Neurosurgery. 2004 Apr;54(4):925-31; discussion 931-3.

14. Inaba K, Recinos G, Teixeira PG, Barmparas G, Talving $\mathrm{P}$, Salim A, et al. Complications and death at the start of the new academic year: is there a July phenomenon? J Trauma. 2010 Jan;68(1):19-22.

15. Kestle JR, Cochrane DD, Drake JM. Shunt insertion in the summer: is it safe? J Neurosurg. 2006 Sep;105(3 Suppl): 165-8.

16. Kowalski RG, Claassen J, Kreiter KT, Bates JE, 
Ostapkovich ND, Connolly ES, et al. Initial misdiagnosis and outcome after subarachnoid hemorrhage. JAMA. 2004 Feb;291(7):866-9.

17. Kraus JJ, Metzler MD, Coplin WM. Critical care issues in stroke and subarachnoid hemorrhage. Neurol Res. 2002;24(Suppl 1):S47-57.

18. Landrigan $\mathrm{CP}$, Rothschild JM, Cronin JW, Kaushal R, Burdick E, Katz JT, et al. Effect of reducing interns' work hours on serious medical errors in intensive care units. N Eng J Med. 2004 Oct;351(18):1838-48.

19. Lockley SW, Cronin JW, Evans EE, Cade BE, Lee CJ, Landrigan $\mathrm{CP}$, et al. Effect of reducing interns' weekly work hours on sleep and attentional failures. $\mathrm{N}$ Engl J Med. 2004 Oct;351(18):1829-37.

20. McDonald RJ, Cloft HJ, Kallmes DF. Impact of admission month and hospital teaching status on outcomes in subarachnoid hemorrhage: evidence against the July effect. J neurosurg. 2012 Jan;116(1):157-63.

21. Myles TD. Is there an obstetric July phenomenon? Obstet Gynecol. 2003 Nov;102(5 pt 1):1080-4.

22. Pape HC, Pfeifer R. Restricted duty hours for surgeons and impact on residents quality of life, education and patient care: a literature review. Patient Saf Surg. 2009 Feb;3(1):3.

23. Phillips DP, Barker GE. A July spike in fatal medication errors - a possible effect of new medical residents. J Gen Intern Med. 2010 Aug;25(8):774-9.

24. Rich EC, Gifford G, Luxenberg M, Dowd B. The relationship of house staff experience to the cost and quality of inpatient care. JAMA. 1990 Feb;263(7):953-7.

25. Rich ED, Hillson SD, Dowd B, Morris N. Specialty differences in the "July Phenomenon" for Twin Cities teaching hospitals. Med Care. 1993 Jan;31(1):73-83.

26. Shulkin DJ. The July phenomenon revisited : are hospital complications associated with new house staff? Am J Med Qual. 1995 Spring;10(1):14-7.

27. Smith ER, Bulter WE, Barker FG 2nd. Is there a "July phenomenon" in pediatric neurosurgery at teaching hospitals? J Neurosurg. 2006 Sep;105(3 Suppl):169-76.

28. Walling HW, Veremakis C. Ordering errors by first-year residents: evidence of learning from mistakes. Mo Med. 2004 Mar-Apr;101(2):128-31. 